withdraw consent to continued use of an intervention (as in our case), ${ }^{1}$ but not to demand that any specific physician perform the withdrawal, nor to provide additional or alternative interventions.

Why would physicians feel moral distress? The "trolley train" and "footbridge" dilemmas ${ }^{4}$ show that once an increasing emotional valence weighs on a decision, most individuals become less pragmatic and lean to values associated with adherence to obligation. $^{4,5}$ Thus, most clinicians would hesitate to extubate ventilator-dependent patients. If the extubation imposed on the physician's moral principles, we would agree that doctors might pursue conscientious objection and thus protect their moral center.

Nina F. Schor, Rochester, NY: Dr. Pullicino is correct that the physician is free to-and probably should-establish a moral line over which he or she will not tread. It is then the obligation of that physician to make this judgment known to the patient.
Furthermore, the physician would then recuse himself or herself from the patient's care when the wishes of the patient would require that the physician cross that line.

(C) 2015 American Academy of Neurology

1. Daly B, Gokhale S, Ramos-Estebanez C. Clinical and ethical judgment: a profound dilemma. Neurology 2014; 83:1369-1371.

2. Schor NF. Comment: autonomy vs beneficence. Neurology 2014;83:1370.

3. Bernardin JC. Renewing the covenant with patients and society: address to the American Medical Association House of Delegates, Washington, D.C., December 5th, 1995. CSA Bull 2009;58:52-59.

4. Greene JD, Sommerville RB, Nystrom LE, Darley JM, Cohen JD. An fMRI investigation of emotional engagement in moral judgment. Science 2001;293:2105-2108.

5. Koenigs M, Young L, Adolphs R, et al. Damage to the prefrontal cortex increases utilitarian moral judgments. Nature 2007;446:908-911.

\title{
CORRECTIONS
}

$S P G 7$ mutations are a common cause of undiagnosed ataxia

In the Clinical/Scientific Note "SPG7 mutations are a common cause of undiagnosed ataxia" by G. Pfeffer et al. (Neurology ${ }^{\circledR}$ 2015;84:1174-1176), there were omissions to the study funding, which should have included the following: "A.H.N. receives support from Action Medical Research and the Henry Smith Charity and the NIHR. J.M. receives support from Action Medical Research and the Henry Smith Charity. K.F. and D.S. are funded by the Medical Research Council (UK) Computational Genomics Analysis and Training programme (G1000902)." The authors regret the omissions.

\section{Vigabatrin retinal toxicity in children with infantile spasms: An observational cohort study}

In the article "Vigabatrin retinal toxicity in children with infantile spasms: An observational cohort study" by C.A. Westall et al. (Neurology ${ }^{\circledR} 2014 ; 83: 2262-2268$ ), there is an error in the article processing charge (APC) note. The APC was not paid by Canadian Institutes of Health Research. 


\section{Neurology}
Vigabatrin retinal toxicity in children with infantile spasms: An observational cohort study
Neurology 2015;84;1911
DOI 10.1212/WNL.0000000000001631

This information is current as of May 4, 2015

$\begin{array}{ll}\begin{array}{l}\text { Updated Information \& } \\ \text { Services }\end{array} & \begin{array}{l}\text { including high resolution figures, can be found at: } \\ \text { http://n.neurology.org/content/84/18/1911.2.full }\end{array} \\ \text { Permissions \& Licensing } & \begin{array}{l}\text { Information about reproducing this article in parts (figures,tables) or in } \\ \text { its entirety can be found online at: } \\ \text { http://www.neurology.org/about/about_the_journal\#permissions }\end{array} \\ \text { Reprints } & \begin{array}{l}\text { Information about ordering reprints can be found online: } \\ \text { http://n.neurology.org/subscribers/advertise }\end{array}\end{array}$

Neurology ${ }^{\circledR}$ is the official journal of the American Academy of Neurology. Published continuously since 1951, it is now a weekly with 48 issues per year. Copyright (C 2015 American Academy of Neurology. All rights reserved. Print ISSN: 0028-3878. Online ISSN: 1526-632X.

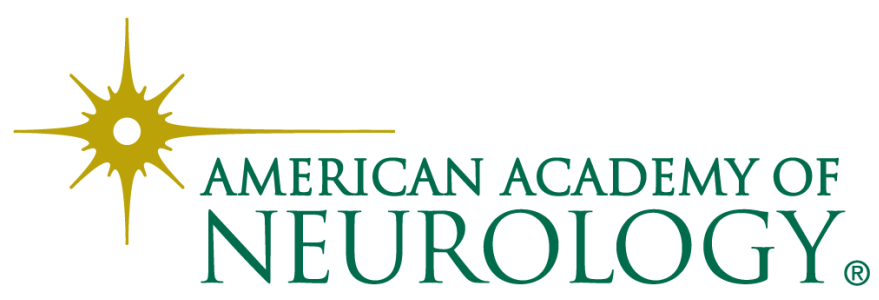

